\title{
Preparation of enzymatic hydrolysate from defatted perilla seed residue and its application to Leuconostoc mesenteroides cultivation
}

\author{
Yeung Sub Shin ${ }^{1} \cdot$ Tae Jung Lee ${ }^{1} \cdot$ Man-Jin In $^{1} \cdot$ Dong Chung Kim ${ }^{1}$ \\ 탈지 들깨박 효소분해물의 제조와 Leuconostoc mesenteroides 배양에의 \\ 활용
}

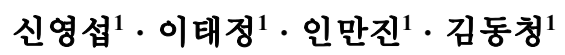

Received: 12 January 2021 / Accepted: 23 February 2021 / Published Online: 31 March 2021

(C) The Korean Society for Applied Biological Chemistry 2021

\begin{abstract}
In this study, enzymes were screened for hydrolysis of defatted perilla seed residue (DPSR) and optimal conditions for enzymatic treatment were determined to produce the hydrolysate of DPSR. Also its antioxidant activity and utilization as a culture medium were examined. The combined treatment of Alcalase and Ceremix is most effective for solubilization of protein and carbohydrate in DPSR. The optimal dosage, $\mathrm{pH}$, and reaction time for enzymatic treatment were found to be $2.0 \%(\mathrm{w} / \mathrm{w}), 7.0$, and $2 \mathrm{~h}$, respectively. Treatment with optimal conditions of enzymes dramatically increased reducing sugar, soluble protein, and total phenolic content. The hydrolysate of DPSR possessed better scavenging activity against cation and free radicals than enzymeuntreated extract. When Leuconostoc mesenteroides 310-12 was cultured in the hydrolysate of DPSR, cell population rapidly increased compared to enzyme-untreated extract, and titratable acidity increased in proportion to the bacterial growth. In conclusion, these results imply that the hydrolysate of DPSR could be utilized as a bacteria culture medium as well as a physiologically active material with antioxidant activity.
\end{abstract}

Dong Chung Kim $(\bowtie)$

E-mail: kimdc@chungwoon.ac.kr

${ }^{1}$ Department of Chemical Engineering, Chungwoon University, Incheon 22100, Republic of Korea

This is an Open Access article distributed under the terms of the Creative Commons Attribution Non-Commercial License (http://creativecommons. org/licenses/by-nc/3.0/) which permits unrestricted non-commercial use, distribution, and reproduction in any medium, provided the original work is properly cited.
Keywords Defatted perilla seed residue $\cdot$ Enzymatic hydrolysis · Leuconostoc mesenteroides · Microbial medium

서 론

들깨(Perilla frutescens)는 식용유지를 얻기 위해 우리나라에서 가장 많이 생산되는 유지작물로 종자에 oleic acid, linoleic acid, $\alpha$-linolenic acid 등 약 $90 \%$ 의 불포화 지방산과 palmitic acid 등 약 $10 \%$ 의 포화지방산으로 구성된 양질의 지방이 $40 \%$ 이상 함유되어 있으며[1], rosmarinic acid와 ursolic acid 등과 같은 phenolic 화합물과 terpenoid 성분에 의한 항산화, 항염증 등의 생리활성도 보고된 우수한 식품재료이다[1,2]. 들깨 종자에 약 $16 \%$ 함유되어 있는 단백질은 참깨 단백질[3] 과 유사하게 함황 아미노산이자 필수 아미노산인 methionine의 함량이 우수 하여[1] 대두와 같이 상대적으로 methionine이 부족한 식품의 영양학적 특성을 보완할 수 있는 잠재력을 갖은 식품소재이다. 영양학적인 효과뿐만 아니라 들깨 단백질 가수분해물에는 유화 와 거품 형성에 효과적인 펩타이드[4], 항산화 활성[5-7]과 $\alpha$ glucosidase와 $\mathrm{ACE}$ 저해 활성을 갖는 펩타이드[6,7]가 존재한다 는 보고를 참고하면 들깨 단백질은 식품 가공 및 생리활성 소 재로도 유용한 자원이다.

들깨 종자의 착유로 발생되는 부산물인 들깨박은 단백질과 탄수화물이 각각 $30 \sim 40 \%$ 함유되어 있으며 $[8,9]$, 다양한 항산화 phenolic 화합물도 존재하므로[10] 단백질, 탄수화물, phenolic 화합물의 공급원으로 활용이 가능한 자원이나 대부분은 사료[9] 로 이용되거나 폐기되고 있다. 들깨박 phenolic 화합물의 활용 을 위하여는 주로 들깨박 에탄올이나 메탄올 추출물의 항산화, 
항돌연변이, 항염증 활성 등을 조사하였다[11-13]. 들깨박 단백 질 활용을 위하여 산과 알칼리를 사용하는 화학적인 방법 $[8,14]$, 초음파를 이용한 물리적인 방법[15] 및 효소 처리[4-7] 등의 방 법으로 추출하는 보고가 있으며, 식품 소재로 들깨 단백질을 이 용하기 위하여 단백질 분해효소의 처리로 얻어진 펩타이드의 물 성(용해도, 물과 기름 흡수력, 유화능과 거품 형성능)에 관한 보 고[4,6]도 있다. 들깨박에 단백질 분해효소를 사용하는 연구[4$8]$ 는 대부분 들깨박 현탁액을 알칼리로 처리하여 들깨박 단백 질을 추출한 후 단백질 분해효소를 사용하는 것으로 단백질을 분리하는 전처리 공정이 포함되어 있다. 또한 들깨박 다당류의 추출을 위하여 초음파와 알칼리를 동시에 사용하는 물리·화학 적인 방법[16]과 상업용 효소인 Celluclast $1.5 \mathrm{~L}$ 과 Viscozyme $\mathrm{L}$ 을 사용하는 효소 처리법[17] 등이 보고되어 있으나, 효소 처 리법은 단백질 분해효소의 처리와 유사하게 들깨박 자체를 사 용하지 않고 미리 제조한 들깨박의 cellulose와 hemicellulose 분 획을 기질로 사용하였다. 즉, 효소를 이용한 들깨박 단백질과 탄수화물을 활용하기 위한 기존의 연구[4-8,17]는 들깨박의 전 처리로 다당류나 단백질을 분리한 후 탄수화물 분해효소와 단 백질 분해효소를 각각 처리한 것이며, 들깨박을 직접 기질로 사 용하면서 탄수화물 분해효소와 단백질 분해효소의 처리 조건에 관한 연구는 미미하다.

따라서 본 연구에서는 들기름 제조공정의 부산물로 생성되는 들깨박의 불용성 물질을 가용화하여 생리활성의 변화 및 미생 물 배양 배지로서의 가능성을 확인함으로써 들깨박의 산업적 활 용을 위한 기초 자료를 제시하자고 하였다. 들깨박을 직접 기 질로 하여 상업용 단백질 및 탄수화물 분해효소를 선별하고, 효 소처리 조건을 확립하였다. 또한 효소분해로 얻어진 들깨박 효 소분해물의 항산화 활성 및 젖산균 배양배지로서의 활용가능성 을 효소처리하지 않은 들깨박과 비교하였다.

\section{재료 및 방법}

\section{실험재료}

탈지 들깨박은 경상남도 창원시 마산합포구 진전면에서 수확한 들깨에서 들깨유를 제조 후 부산물로 얻어지는 것을 이용하였 다. Alcalase, Flavourzyme, Neutrase, Protamex, Ceremix, Pectinase, Viscozyme은 Novozyme사(Bagsvaerd, Denmark)의 제품을 사용 하였다. D-glucose, 3,5-dinitrosalicylic acid (DNS), bovine serum albumin (BSA), Bradford 시약, 1,1-diphenyl-2-picrylhyrazyl (DPPH), 2,2'-azino-bis-3-ethylbenzothiazoline-6-sulfonic acid (ABTS), Folin-Ciocalteu 시약, gallic acid는 Sigma Aldrich (St. Louis, MO, USA) 제품을 사용하였다. 젓산균은 김치에서 분리한 Leuconostoc mesenteroides 310-12 균주[18]를 Difco사 (Detroit, MI, USA)의 Lactobacilli MRS agar 배지에 계대배양 하여 사용하였다.

\section{들깨박 효소처리}

들깨박의 가용화를 위해 단백질 분해효소인 Alcalase, Flavourzyme, Neutrase, Protamex와 탄수화물 분해효소인 Ceremix, Pectinase, Viscozyme을 사용하였다. 들깨박은 분쇄한 후 $200 \mathrm{mesh}$ 체로 분리한 분말을 실험에 사용하였다. 증류수에 들깨박 분말을 $10 \%$ $(\mathrm{w} / \mathrm{w})$ 로 현탁시킨 시료를 열처리 $\left(121^{\circ} \mathrm{C}, 20 \mathrm{~min}\right)$ 하고 실온에서 충분히 냉각시킨 후 $0.1 \mathrm{~N} \mathrm{NaOH}$ 혹은 $\mathrm{HCl}$ 로 각각의 효소 반 응 최적 $\mathrm{pH}$ 로 조절한 다음 효소를 들깨박 중량의 $1 \%(\mathrm{w} / \mathrm{w})$ 로 가하여 각각의 효소 반응 최적 온도에서 2 시간 동안 진탕하였 다. 반응 종료 후 끓는 물에 5분간 열처리하고 원심분리 $\left(3,000 \times \mathrm{g}, 10 \mathrm{~min}, 4{ }^{\circ} \mathrm{C}\right)$ 하여 상등액을 분석 시료로 활용하였다. 효소를 첨가하지 않고 같은 조건으로 처리한 들깨박 현탁액의 상등액을 대조군으로 하였다.

들깨박의 효소 처리 조건을 결정하였다. 들깨박의 효소처리 는 탄수화물 분해효소(Ceremix)와 단백질 분해효소(Alcalase)를 $1: 1$ 비율로 동시에 첨가하는 반응조건을 조사하였다. 최적 $\mathrm{pH}$ 를 확인하기 위하여 열처리한 들깨박 $10 \%(\mathrm{w} / \mathrm{w})$ 현탁액을 다 양한 $\mathrm{pH}(\mathrm{pH}$ 5.0 8.0)로 조절하고 Ceremix와 Alcalase를 각각 들깨박 중량의 $0.5 \%$ 첨가한 후 $50{ }^{\circ} \mathrm{C}$ 에서 2 시간 반응시킨 다 음 열처리와 원심분리하여 얻은 상등액을 분석하였다. 최적 효 소 사용량은 열처리한 들깨박 $10 \%(\mathrm{w} / \mathrm{w})$ 현탁액 $(\mathrm{pH} 7.0)$ 에 Ceremix와 Alcalase를 각각 들깨박 중량의 $0.25 ~ 1.5 \%$ 첨가하고 $50{ }^{\circ} \mathrm{C}$ 에서 2 시간 반응시킨 후 동일한 방법으로 준비한 상등액 을 분석하여 결정하였다. 효소 반응시간은 열처리 들깨박 현탁 액 $(10 \%, \mathrm{pH} 7.0)$ 에 Ceremix와 Alcalase를 각각 들깨박 중량의 $1 \%$ 로 첨가하고 $50{ }^{\circ} \mathrm{C}$ 에서 $0 \sim 3$ 시간 반응시킨 후 동일한 방법으 로 준비한 상등액을 분석하여 결정하였다.

실험 결과는 SPSS Statistics (Statistical Package for Social Science, SPSS Inc., Chicago, IL, USA, version 23.0)를 이용 하여 $\mathrm{t}$-검정으로 시료간 유의성을 조사하였다(유의수준 $p<0.05$ ).

\section{환원당, 단백질 및 폴리페놀 함량}

효소처리와 원심분리를 통하여 얻은 상등액의 환원당 함량은 각 각 포도당을 표준물질로 $\mathrm{DNS}$ 법으로, 단백질 함량은 $\mathrm{BSA}$ 를 표 준물질로 Bradford법으로 분석하였다. 또한 폴리페놀 함량은 Folin-Ciocalteu 시약을 사용하여 Folin과 Denis의 방법[19]으로 분석하였고, 함량은 gallic acid equivalent $(\mathrm{GAE})$ 로 나타내었다.

\section{들깨박 효소분해물의 항산화 활성}

$\mathrm{DPPH}$ 유리 라디칼 소거 활성은 Blois 방법[20]으로 확인하였 는데, 들깨박 효소분해물 $0.2 \mathrm{~mL}$ 에 에탄올 $2 \mathrm{~mL}$ 와 $0.2 \mathrm{mM}$ $\mathrm{DPPH}$ 용액 $0.8 \mathrm{~mL}$ 를 혼합하여 상온에서 30 분 방치한 후 517 $\mathrm{nm}$ 에서 흡광도를 측정하였다. $\mathrm{ABTS}$ 양이온 라디칼 소거 활성 은 $\operatorname{Re}$ 등의 방법[21]으로 측정하였는데, 들깨박 효소분해물 0.1 $\mathrm{mL}$ 와 $\mathrm{ABTS}$ 용액(흡광도: $1.5 \pm 0.2$ ) $3.0 \mathrm{~mL}$ 를 혼합하여 상온에 서 1.5 시간 방치한 후 $414 \mathrm{~nm}$ 에서 흡광도를 측정하였다. $\mathrm{DPPH}$ 와 $\mathrm{ABTS}$ 라디칼 소거활성 $(\%)$ 은 [(증류수 첨가군 흡광도 - 시 료 흡광도)/증류수 첨가군 흡광도] $\times 100$ 의 식으로 계산하였다.

\section{미생물 배양}

Leuconostoc mesenteroides 310-12 균주를 Lactobacilli MRS broth에 $36{ }^{\circ} \mathrm{C}$ 에서 19 시간 동안 종배양하고 배양액를 원심분리 $\left(3000 \times \mathrm{g}, 10 \mathrm{~min}, 4^{\circ} \mathrm{C}\right)$ 하여 균체를 회수한 다음 멸균 식염수로 2 회 세척한 후 균체를 배양액과 동일 부피의 멸균 식염수에서 현탁하였다. 다른 영양성분을 첨가 하지 않고 멸균하여 준비한 들깨박 효소분해물에 균주 현탁액을 $5 \%(\mathrm{v} / \mathrm{v})$ 로 접종하고 $36{ }^{\circ} \mathrm{C}$ 에서 $180 \mathrm{rpm}$ 으로 15 시간 동안 진탕 배양하면서 균의 생육, 
$\mathrm{pH}$, 적정산도의 변화를 경시적으로 측정하였다. 배양액의 $\mathrm{pH}$ 는 $\mathrm{pH}$ meter로 직접 측정하였으며, 적정산도는 희석한 배양액 10 $\mathrm{mL}$ 를 phenolphthalein을 지시약으로 $0.01 \mathrm{~N} \mathrm{NaOH}$ 로 적정하여 젖산 함량으로 표시하였다. 균의 생육 정도는 $610 \mathrm{~nm}$ 의 흡광도 를 측정하여 모니터링하였다. 대조군으로는 들깨박 미분해물을 사용하였다.

\section{결과 및 고찰}

\section{들깨박 분해효소 선별}

탈지 들깨박에 각각 $30 \sim 40 \%$ 함유되어 있는 탄수화물과 단백질 을 효소 처리로 가용화하기 위하여 상업용 탄수화물과 단백질 분해효소를 각각 선별하였다. $10 \%(\mathrm{w} / \mathrm{w})$ 들깨박 현탁액에 들 깨박 중량의 $1 \%$ 로 효소를 첨가하여 반응시킨 후 효소 처리 상 등액의 탄수화물과 단백질 함량을 분석하여 효소를 첨가하지 않 고 단순 추출한 대조군과 비교하였다(Table 1). 환원당의 함량 은 Ceremix $>$ Alcalase $\geq$ Viscozyme $>$ Protamex $>$ Flavourzyme $>$ Neutrase $>$ Pectinase 순으로 대조군보다 27.0 68.9\%, 단백질 함량은 Alcalase $>$ Protamex $>$ Neutrase 순으로 대조군 보다 $3.5 \sim 21.9 \%$ 증가하였다. Ceremix는 $\alpha$-amylase, $\beta$-glucanase, cellulase, pentosanase 등의 혼합효소제제로 환원당 함량을 대조 군 대비 약 $70 \%$, Alcalase는 단백질 함량을 대조군 대비 $20 \%$ 이상 향상시키는 효과가 있었다. 따라서 들깨박의 탄수화물 분 해에는 Ceremix, 단백질 분해에는 Alcalase를 사용하는 것이 적 절하다고 사료된다. 본 연구가 들깨박 단백질의 가수분해에서 Flavourzyme이 Alclase보다 높은 가수분해도를 보인다는 결과 [22]와 상이한 것은 단백질 분리없이 들깨박을 효소의 기질로 사용한 차이가 원인으로 판단된다. 또한, 본 연구에서 단백질 분해효소의 처리로 환원당의 함량이 증가하는 것은 들깨박에 존 재하는 당단백질 복합체의 단백질 부분을 가수 분해하여 다당 류와 단백질의 용해도를 증가시키는데 기인한 것으로 여겨진다 [23]. 이러한 경향은 단백질 분해효소인 Alcalase, Flavourzyme 등으로 홍삼박[24]이나 톳[25]을 분해하였을 때 대조군 보다 환 원당 함량이 더 높게 나타난다는 보고와 매우 유사하였다.

\section{들깨박 효소분해물 제조}

선별한 단백질 분해효소 Alcalase와 탄수화물 분해효소 Ceremix 의 반응 조건 $(\mathrm{pH}$, 효소 첨가량 및 반응시간)의 영향을 조사하 였다. 두 종류 이상의 효소를 하나의 기질에 처리하는 경우 반 응조건이 유사하면 두 효소를 동시에[24], 특히 반응 $\mathrm{pH}$ 가 상 이한 경우에는 순차적으로[26] 사용하는 것이 효과적일 수 있 다. 본 연구의 Ceremix는 $\mathrm{pH} 5.0$, Alcalase는 $\mathrm{pH}$ 6.5 8.5에서 최대 활성을 보이나 공정의 간편성과 Alcalase의 넓은 $\mathrm{pH}$ 조건 을 고려하여 두 효소를 동시에 처리하기 위한 최적의 $\mathrm{pH}$ 조건 을 조사하였다. 이때 들깨박과 효소를 증류수에 넣고 $\mathrm{pH}$ 를 조 절하지 않은 것을 대조군으로 하였다. 각각의 실험군은 열처리 한 들깨박 $10 \%(\mathrm{w} / \mathrm{w})$ 현탁액을 $\mathrm{pH} \quad 5.0 \sim 8.0$ 로 조절하고 Ceremix와 Alcalase를 각각 들깨박 중량의 $0.5 \%$ 씩 첨가한 후 $50{ }^{\circ} \mathrm{C}$ 에서 2 시간 반응시키고 상등액의 환원당과 단백질 함량을 대조군과 비교하였다(Fig. 1A), 환원당 함량은 $\mathrm{pH}$ 7에서, 단백 질 함량은 $\mathrm{pH}$ 8에서 공히 대조군보다 2 배 증가하였다. 환원당
Table 1 Effects of various enzyme treatments on the solubilization of defatted perilla seed residue

\begin{tabular}{ccc}
\hline \hline Enzymes & $\begin{array}{c}\text { Relative protein content } \\
(\%)\end{array}$ & $\begin{array}{c}\text { Relative reducing } \\
\text { sugar content }(\%)\end{array}$ \\
\hline Alcalase & $121.93 \pm 16.45^{1)}$ & $146.62 \pm 16.24$ \\
Flavourzyme & $32.27 \pm 4.51^{*}$ & $133.78 \pm 26.76$ \\
Nutrase & $103.53 \pm 8.00$ & $129.73 \pm 7.64$ \\
Protamex & $117.06 \pm 17.77$ & $135.81 \pm 8.60$ \\
Ceremix & $90.19 \pm 10.01$ & $168.92 \pm 0.61^{*}$ \\
Pectinase & $59.11 \pm 7.56^{*}$ & $127.03 \pm 7.64$ \\
Viscozyme & $65.65 \pm 2.39^{*}$ & $145.95 \pm 34.40$ \\
Control & $100 \pm 15.63$ & $100 \pm 11.45$ \\
\hline
\end{tabular}

${ }^{1)}$ Values were means $\pm \mathrm{SD}(\mathrm{n}=3)$

${ }^{2)}$ Data were statistically different from the value of control $\left({ }^{*} p<0.05\right)$ by t-test

함량은 $\mathrm{pH}$ 6 8에서, 단백질 함량은 $\mathrm{pH}$ 7 8에서 큰 차이를 보 이지는 않았으나 미생물 배지로 활용하기 위하여 환원당이 많 이 생성되는 $\mathrm{pH}$ 7을 반응 조건으로 선택하였다. 두 효소의 최 적 첨가량을 설정하기 위하여 들깨박 $10 \%(\mathrm{w} / \mathrm{w})$ 현탁액 $(\mathrm{pH}$ 7.0)에 Ceremix와 Alcalase를 각각 들깨박 중량의 $0.25 ~ 1.5 \%$ 첨가하고 $50{ }^{\circ} \mathrm{C}$ 에서 2 시간 반응시키고 상등액의 환원당과 단백 질 함량을 측정하였다(Fig. $1 \mathrm{~B}$ ). 가용화된 환원당과 단백질 함 량은 유사하게 효소 처리 농도 $1.0 \%$ 까지 급격하게 증가한 후 $2 \%$ 까지 매우 완만하게 증가하였다. 따라서 효소반응액의 환원 당과 단백질 함량을 고려하면 총 효소 첨가량은 $2 \%(\mathrm{w} / \mathrm{w})$ (Ceremix와 Alcalase 각 $1 \%$ )가 가장 적절한 것으로 여겨진다. 이는 스피루리나 추출물의 제조 시 Alcalase $1 \%$ 이상의 조건 에서 고형분 회수율의 변화가 미미하다는 보고[27]와도 잘 일 치하였다. 효소 반응시간을 결정하기 위하여 Ceremix와 Alcalase 를 각각 $1 \%$ 조건에서 반응시간에 따른 환원당과 단백질 함량 의 변화를 조사하였다(Fig. $1 \mathrm{C}$ ). 환원당 함량은 3시간까지 시간 에 비례하여 지속적으로 증가하였으나, 단백질 함량은 반응 2 시간 후 증가하지 않는 양상을 보였다. 이러한 결과는 Alcalase 로 유청 단백질을 가수분해하는 보고[28]에서 반응 50 분까지 가 수분해가 급속히 증가한 후 반응 150 분 이후 감소되는 결과와 유사하였다. 따라서 반응시간에 따른 단백질 함량의 증가를 고 려하면 들깨박에 Ceremix와 Alcalase의 효소 반응 시간은 2시 간이 적절하였다. 이상의 반응 조건으로 효소 처리한 결과 상 등액의 환원당과 단백질 함량은 각각 6.87 과 $3.22 \mathrm{mg} / \mathrm{mL}$ 이었 다. 이는 효소 처리하지 않은 들깨박 추출물(대조군)의 환원당 과 단백질 함량이 각각 4.36 과 $2.67 \mathrm{mg} / \mathrm{mL}$ 인 것에 비해 상당 히 높게 나타났다.

\section{들깨박 효소분해물의 항산화 활성}

본 연구에서 확립된 방법으로 제조한 들깨박 효소분해물의 $\mathrm{ABTS}$ 양이온 라디칼 소거 활성과 $\mathrm{DPPH}$ 유리 라디칼 소거 활 성으로 항산화 활성을 조사하여 대조군과 비교하였다(Fig. 2). 양이온 라디칼 소거능은 들깨박 $13.9 \mathrm{mg} / \mathrm{mL}$ 농도에서 효소분 해물은 $67.39 \pm 0.70 \%$ 로 대조군의 $48.37 \pm 0.27 \%$ 보다 약 $20 \%$ 증가하였으며, 유리 라디칼 소거능은 들깨박 $11.1 \mathrm{mg} / \mathrm{mL}$ 농도 에서 효소분해물은 $86.52 \pm 0.48 \%$ 로, 대조군의 $39.93 \pm 1.02 \%$ 보다 

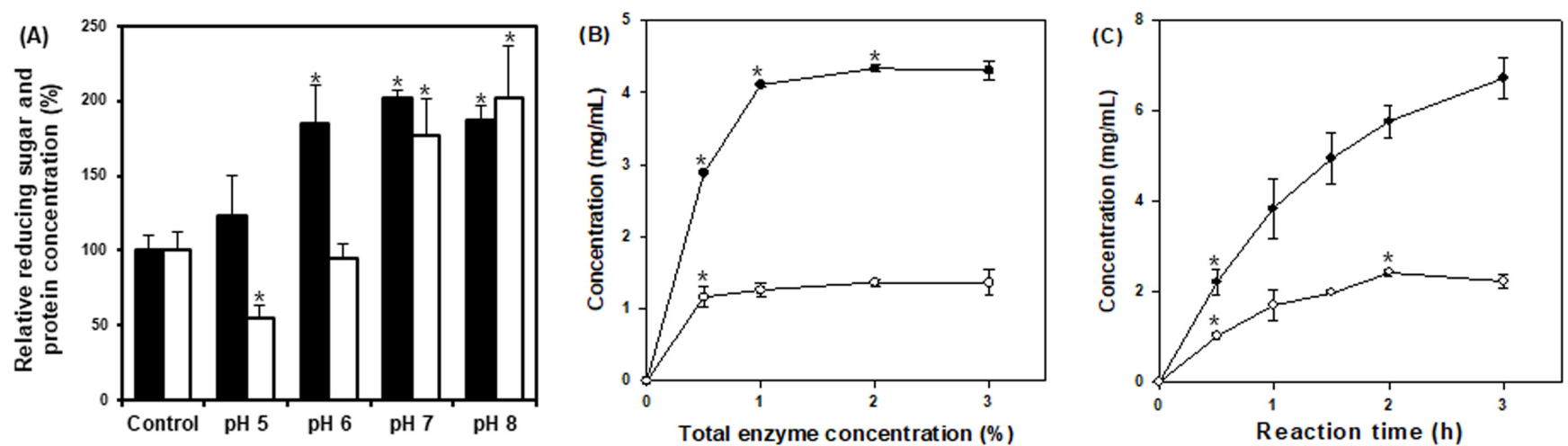

Fig. 1 Effects of reaction pH (panel A), enzyme concentration (panel B) and reaction time (panel C) of Ceremix and Alcalase co-treatment on reducing sugar concentration (closed symbols) and protein concentration (open symbols) in defatted perilla seed residue hydrolysate. All data were means \pm SD $(\mathrm{n}=3)$. Data were statistically different from the value of control (panel A) and previous group (panel B and C), respectively $\left({ }^{*} p<0.05\right)$

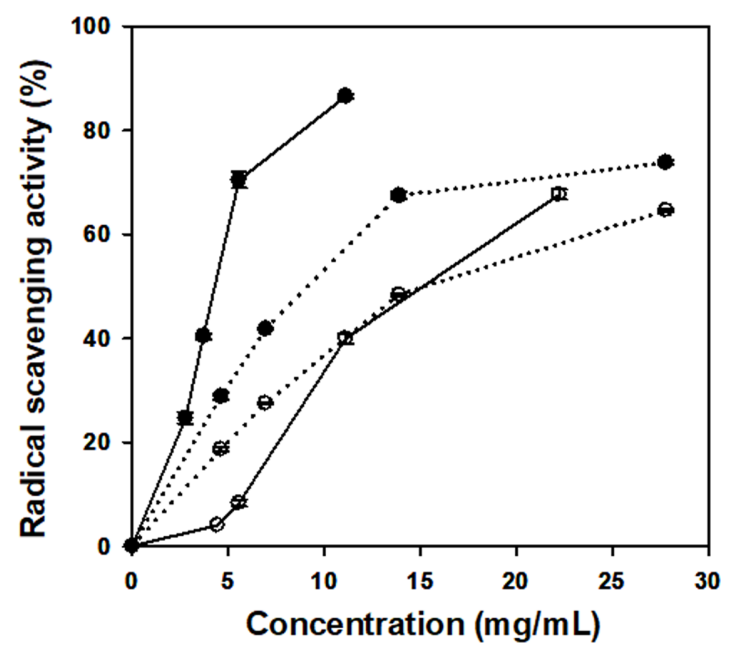

Fig. 2 Antioxidative activities of enzyme-treated hydrolysates (closed symbols) and enzyme-untreated control (open symbols) of defatted perilla seed residue. Solid line, DPPH free radical scavenging activities; dotted line, ABTS cation radical scavenging activities. All data were means $\pm \mathrm{SD}(\mathrm{n}=3)$

2배 이상 증가하였다. 항산화 활성은 효소분해물과 대조군 모두 농도 의존적인 경향을 보였으나 효소분해물에서 항산화 활성이 크게 증가하였다. 폴리페놀 함량과 항산화 활성이 비례한다는 기존의 보고[10,29]를 참고하면, 본 연구의 결과도 효소처리에 의하여 효소분해물의 폴리페놀 함량 $(1.64 \mathrm{mg} \mathrm{GAE} / \mathrm{mL})$ 이 대조 군 $(0.69 \mathrm{mg} \mathrm{GAE} / \mathrm{mL})$ 보다 2 배 이상 증가된 것에 기인하는 것 으로 판단된다. 또한 효소 처리에 의하여 식물 조직의 파괴 [30,31] 및 배당체 형태로 존재하는 폴리페놀 화합물이 유리형 으로 전환[32] 등에 의하여 폴리페놀 화합물의 추출이 향상되 었다는 보고와 일치하는 결과이다. Jeong 등[10]은 들깨박으로 부터 10 종의 폴리페놀 화합물을 분리하여 rosmarinic acid와 protocatechuic aldehyde의 DPPH 라디칼 소거활성이 가장 우수 함을 보여주었다. 또한 들깨박에서 분리한 단백질을 단백질 분 해효소로 처리한 가수분해물에서 항산화 활성을 보이는 펩타이 드에 관한 보고 $[5,8,22]$ 를 함께 고려하면 본 연구의 효소분해물

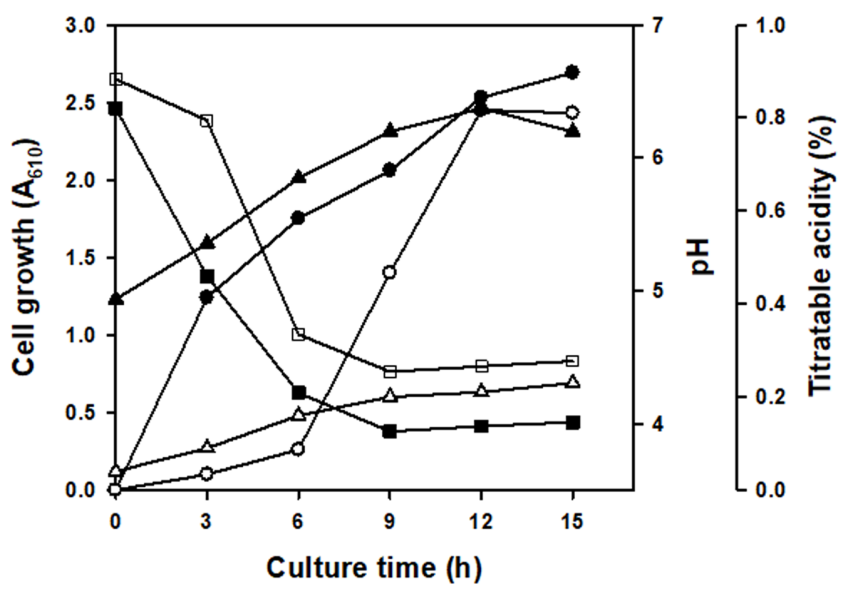

Fig. 3 Changes in cell growth $(\bigcirc)$ of Leuconostoc mesenteroides 310-12 and in $\mathrm{pH}(\square)$ and titratable acidity $(\triangle)$ of enzyme-treated hydrolysates medium (closed symbols) and enzyme-untreated control medium (open symbols) of defatted perilla seed residue during cultivation at $36{ }^{\circ} \mathrm{C}$

의 항산화 활성은 폴리페놀 화합물과 Alcalase에 작용으로 생성 된 펩타이드에 기인하는 것으로 사료된다.

\section{들깨박 효소분해물에서 젓산균 배양}

들깨박 효소분해물의 미생물 배양 배지로서의 활용 가능성을 조 사하기 위하여 본 연구에서 확립된 방법으로 제조한 들깨박 효 소분해물과 효소를 사용하지 않은 추출물(대조군)에 Leuconostoc mesenteroides 310-12 균주를 접종하고 $36^{\circ} \mathrm{C}$ 에서 진탕 배양하 면서 경시적으로 균의 생육, 적정산도와 $\mathrm{pH}$ 의 변화를 비교하였 다(Fig. 3). 발효시간에 따른 배양액의 $\mathrm{pH}$ 는 배양 9시간까지 효 소분해물 배지에서 대조군 보다 빠르게 감소하였으며 낮은 값 을 보였다(효소처리군, $6.37 \rightarrow 3.94$; 대조군, $6.59 \rightarrow 4.39$ ). 적정산 도는 $\mathrm{pH}$ 변화와 동일한 경향으로 배양 9 시간 후 효소분해물 배 지에서 $0.77 \%$ 까지 증가하였으나, 대조군에서는 $0.20 \%$ 로 측정되 었다. 또한 효소분해물에서 젖산균은 접종 후 빠르게 생육이 진 행되어 배양 15 시간까지 지속적인 성장을 보였으나, 대조군에 서는 접종 후 약 6시간의 지연기(lag phase)가 관찰되었으며 배 
양 15 시간 후 생육 정도는 유사하였다. 배양 초기의 빠른 성장 과 산의 생성은 들깨박의 효소 처리로 환원당과 단백질 함량의 증가에 기인하는 것으로 사료된다. 이상의 결과는 단순 추출물 보다 효소분해물이 미생물의 생육에 효과적임을 나타내는 것으 로, 홍삼박[24], 현미[18,33], 흑마늘[34]에서 보고된 결과와 매 우 유사한 경향이다. 본 연구에서는 들깨박 효소분해물을 특별 한 영양 성분의 추가 없이 그대로 미생물 배양 배지로 사용하 였는데, 기존의 $10 \%$ 탈지분유에 상업용 혼합 젖산균을 15 시간 배양한 요거트 제조 결과 $(\mathrm{pH} 3.9$, 적정산도 $0.93 \%)[35]$ 와 산의 생성을 비교해 보아도 들깨박 효소분해물은 미생물 배양 배지 로 충분히 활용 가능하다고 판단된다.

\section{초록}

본 연구에서는 들깨(Perilla frutescens)박으로부터 효소분해물을 제조하기 위한 효소를 선별하여 최적의 반응조건을 확립하였다. Alcalase와 Ceremix의 동시 처리가 들깨박의 단백질과 탄수화 물의 가용화에 효과적이었으며, 효소 사용량은 들깨박 중량의 $2 \%(\mathrm{w} / \mathrm{w}), \mathrm{pH}$ 는 7.0 , 반응 시간은 2 시간이 적당하였다. 최적의 반응조건에서 들깨박을 Alcalase와 Ceremix로 처리한 결과 환 원당, 가용성 단백질 및 총 폴리페놀 함량이 크게 증가하였다. 유리 라디칼과 양이온 라디칼에 대한 소거활성으로 확인한 결 과 들깨박 효소분해물의 항산화 활성은 대조군에 비해 우수하 였다. 또한 젖산균인 Leuconostoc mesenteroides 310-12 균주를 들깨박 효소분해물에서 배양한 결과 대조군에 비해 생육과 산 의 생성이 우수하였다. 결론적으로 들깨박 효소분해물은 항산화 생리활성 소재로서뿐만 아니라 유산균 배양 배지로서도 활용 가 능성이 있음을 확인하였다.

Keywords 들깨박 · 미생물 배지 · 젖산균(Leuconostoc mesenteroides) · 효소 분해

감사의 글 본 논문은 제1저자의 청운대학교 석사학위 논문을 바탕으로 작 성되었습니다.

\section{References}

1. Dhyani A, Chopra R, Garg M (2019) A review on nutritional value, functional properties and pharmacological application of perilla (Perilla frutescens L.). Biomed Pharmacol J 12: 649-660

2. Kim S, Song B, Ju J (2015) Antioxidant activities of Perilla frutescens Britton seed extract and its inhibitory effects against major characteristics of cancer cells. J Korean Soc Food Sci Nutr 44: 208-215

3. Johnson LA, Suleiman TM, Lusas EW (1979) Sesame protein: A review and prospectus. J Am Oil Chem Soc 56: 463-468

4. Park BY, Yoon KY (2019) Functional properties of enzymatic hydrolysate and peptide fractions from perilla seed meal protein. Pol J Food Nutr Sci 69: 119-127

5. Kim JM, Liceaga AM, Yoon KY (2019) Purification and identification of an antioxidant peptide from perilla seed (Perilla frutescens) meal protein hydrolysate. Food Sci Nutr 7: 1645-1655

6. Kim JM, Yoon KY (2020) Functional properties and biological activities of perilla seed meal protein hydrolysates obtained by using different proteolytic enzymes. Food Sci Biotechnol 29: 1553-1562
7. Park BY, Yoon KY (2019) Biological activity of enzymatic hydrolysates and the membrane ultrafiltration fractions from perilla seed meal protein. Czech J Food Sci 37: 180-185

8. Kim JM, Yoon KY (2020) Determination of protein extraction and trypsin hydrolysis conditions for producing hydrolysates with antioxidant activity from perilla seed meal. Korean J Food Preserv 27: 791-799

9. Oh HJ, Son MH, Yun W, Lee JH, An JS, Kim YJ, Kim GM, Kim HB, Cho JH (2020) Effects of replacing soybean meal with perilla seed meal on growth performance, and meat quality of broilers. J Anim Sci Technol 62: 495-503

10. Jeong GH, Jeong YH, Nam JH, Kim TH (2020) Characterization of antioxidant constituents from perilla cake. J Korean Soc Food Sci Nutr 49: 900-906

11. Um MY, Choi WH, An JY, Kim SR, Ha TY (2004) Effect of defatted sesame and perilla methanol extracts on cognitive function and antioxidant activity in SAMP8 mice. Korean J Food Sci Technol 36: 637-642

12. Noh S, Sung J, Lee H, Jeong HS, Kim IH, Lee J (2018) Protective effects of methanol extract of perilla seed meal against oxidative stress in HepG2 cells. Food Sci Technol Res 24: 583-590

13. Chumphukam O, Pintha K, Khanaree C, Chewonarin T, Chaiwangyen W, Tantipaiboonwong P, Suttajit M, Khantamat O (2018) Potential antimutagenicity, antioxidant, and anti-inflammatory capacities of extract from perilla seed meal. J Food Biochem 42: e12556

14. Oita S, Kimura T, Shibuya Y, Nihei N, Tanahashi K (2008) Extraction and digestibility of Perilla frutescens seed proteins. Jpn Agric Res Q 42: 211-214

15. Zhu J, Fu Q (2012) Optimization of ultrasound-assisted extraction process of perilla seed meal proteins. Food Sci Biotechnol 21: 17011706

16. Zhu J, Yang Y, Wen Y, Zhao G (2013) An improved ultrasound-assisted alkali extraction process of perilla seed meal polysaccharide. Sep Sci Technol 48: 2771-2778

17. Hwang YJ, Kim JM, Yoon KY (2020) Characteristics of water-soluble polysaccharide extracts produced from perilla seed meal via enzymatic hydrolysis. CYTA J Food 18: 653-661

18. Kim DC, Choi JW, In MJ (2011) Utilization of Leuconostoc mesenteroides 310-12 strain in the fermentation of a traditional Korean rice-based beverage. J Appl Biol Chem 54: 21-25

19. Folin O, Denis W (1912) On phosphotungstic-phosphomolybdic compounds as color reagents. J Biol Chem 12: 239-243

20. Blois MS (1958) Antioxidant determination by the use of a stable free radical. Nature 181: 1199-1200

21. Re R, Pellegrini N, Proteggente A, Pannala A, Yang M, Rice-Evans C (1998) Antioxidant activity applying an improved ABTS radical cation decolorization assay. Free Radical Biol Med 26: 1231-1237

22. Park BY, Yoon KY (2018) Conditions for hydrolysis of perilla seed meal protein for producing hydrolysates and ultrafiltered peptides and their antioxidant activity. Korean J Food Preserv 25: 605-612

23. Chae HJ, Han MS, In MJ (2004) Study on utilization of vegetable byproduct from food processing by enzyme treatment. J Korean Soc Appl Biol Chem 47: 146-148

24. Kim DC, In MJ (2010) Production of hydrolyzed red ginseng residue and its application to lactic acid bacteria cultivation. J Ginseng Res 34: 321-326

25. Kim HW, Lee JH (2020) Enzymatic extraction of polysaccharide from Hijikia fusiforme and its effects on anti-obesity. J Adv Eng Technol 13: 31-37

26. In MJ (2020) Improvement of protein extraction efficiency from defatted sesame meal with thermal and enzymatic treatments. J Appl Biol Chem 63: 291-295

27. In MJ (2008) Optimization of proteolytic enzyme treatment for the production of spirulina extract. J Korea Acad Industr Coop Soc 90: 550555

28. Costa EL, Rocha Gontijo JA, Netto FM (2007) Effect of heat and 
enzymatic treatment on the antihypertensive activity of whey protein hydrolysates. Int Dairy J 17: 631-640

29. Zhang YB, Bae MJ, An BJ, Choi HJ, Bae JH, Kim S, Choi C (2003) Effect of antioxidant activity and change in quality of chemical composition and polyphenol compound during long-term storage. Korean J Food Sci Technol 35: 115-120

30. Landbo AK, Meyer AS (2001) Enzyme-assisted extraction of antioxidative phenol from black currant juice press residues (Ribes nigrum). J Agric Food Chem 49: 3169-3177

31. Lee PH, Park SY, Jang TH, Yim SH, Nam SH, In MJ, Kim DC, Chae HJ (2014) Effects of complex carbohydrase treatment on physiological activities of pear peel and core. J Korean Soc Food Sci Nutr 43: 404-410

32. Son JY, Jang SH (2013) Physiological activities of enzyme hydrolysates in ethanol extracts from sesame, black sesame and perilla cake. Korean J Food Cookery Sci 29: 407-416

33. In MJ, Oh NS, Kim DC (2009) Characteristics of fermented brown-rice suspension prepared from Leuconostoc mesenteroides KC51 strain. J Korean Soc Food Sci Nutr 38: 1118-1123

34. Chae HJ, Park DI, Lee SC, Oh CH, Oh NS, Kim DC, Won SI, In MJ (2011) Improvement of antioxidative activity by enzyme treatment and lactic acid bacteria cultivation in black garlic. J Korean Soc Food Sci Nutr 40: 660-664

35. Kim DC, Won SI, In MJ (2015) Substitution effect of enzymatically hydrolyzed purple sweet potato powder on skim milk in yogurt preparation. J Appl Biol Chem 58: 311-316 